\title{
Leadership Capability Model for Motivating Junior Secondary School Teachers in Botswana
}

\author{
Luke Moloko Mphale (Corresponding author) \\ Department of Primary Education, University of Botswana \\ Private Bag 00702, Gaborone, Botswana
}

Tel: 267-355-4918Ｅ-mail: mphalelm@mopipi.ub.bw

Received: January 23, 2014 Accepted: February 17, 2014 Published: March 19, 2014

doi:10.5296/ire.v2i1.4974 URL: http://dx.doi.org/10.5296/ire.v2i1.4974

\begin{abstract}
The purpose of the study was to explore types of Leadership Capability Models used by managers of junior secondary schools in Botswana. The focus was to identify appropriate model(s) which can assist the school management to understand their potential in motivating teaching staff. The study was mainly quantitative and used questionnaires to collect data. Some official documents were used to supplement the information collected for the purpose of triangulation. Data were analysed using the Statistical Package for the Social Science or Statistical Product and Service Solutions (SPSS) version 19. The findings of the study revealed that there is no specific leadership model used by the senior management in schools. However, it was also revealed that whichever leadership model that could be used in schools, senior management ought to be confident, competent and self- managing in order to motivate staff effectively. The study, therefore, recommends that the school senior managers should be able to identify the intrinsic and extrinsic motivating factors in order to be good and effective motivators.
\end{abstract}

Keywords: confidence, competent, self-management, motivation, leadership capability model, leadership styles

\section{Introduction}

School leadership has been recognized as an important concept in the lives of teachers by policy makers, parents, students, researchers and practitioners. Over the past ten years, the function which would be identified as leadership has not been consistently referred as such by some scholars (Leithwood \& Jantzi, 2000; MacBeath, 1998). Leadership was not divorced from management and administration. Leadership, management and administration were 
synonymously used when referring to school management. However, recent researches about leadership indicate that concepts of leadership are now being rediscovered (Hendricks, 2006; Wellington, 2012; De Beer \& Rossouw, 2012). Leadership now focuses more on the development and motivation human resource for the success of institutions as opposed to management which is concerned with doing things through people. This implies that the success of any school depends on the effectiveness of its leadership. Finding the appropriate leadership capability model for motivating teachers has been on the agenda for researchers and educators for some years. Senior management with a transformational leadership orientation is reported to have more success in promoting school effectiveness and teachers motivation (Baker, 2011).

In Botswana education system, the use of leadership is also synonymous to administration and management. The policy makers and educators both alike use leadership, administration and management interchangeably (Bennell, 1995). Although there are not many researches carried out in Botswana's education system concerning the impact of leadership on teachers' motivation, there is a call on school leadership to change their mind set (Revised National Policy on Education, 1994). School managers are asked to be visionary leaders with the purpose of motivating their staff. The concept of leadership is now being taken seriously after the innovations brought by the School Management Projects in 1993. Factors mentioned as affecting implementation of the innovations are leadership, motivation and capacity. The assumption is that school leaders have more influence on the quality of their teachers. Quality result is one of the objectives of Botswana education system (Revised National Policy on Education, 1994).

The Botswana government under the Ministry of Education and Skills Development has introduced innovations such as performance management system (PMS), Performance Based Reward System (PBRS), Balance Scorecard and Work Improvement Teams (WITS) to improve school leadership capability. Thorough exploration of the benefits related to the implementation of the innovations has indicated that, school leaders who fully support the innovation are likely to improve their capability, improve effectiveness of their organizations and boost staff motivation (Republic of Botswana, 2003). Despite the evidence of enhanced school leadership capability, improved teachers' motivation and morale, it is not known what leadership capability model does school leadership use to encourage their staff to teach effectively. It is against this backdrop that this study sought to explore Botswana's junior secondary school managers' ideas, experience and understanding of leadership capability models. The study was guided by the following research questions:

i) What is the school managers' understanding of leadership capability model?

ii) What type of a leadership capability model can be used by senior management to motivate teachers?

iii) How effective is the capability model in making school leadership realise their potential?

iv) What factors can contribute towards teachers' motivation?

Before presenting the findings literature related to leadership styles, relationship between 
leadership and management, motivation and leadership model will be discussed.

\section{Literature Review}

There is a growing concern nowadays about the effect of leadership on motivating the teaching staff (Adair, 2012). This is based on a strong belief that leadership and management are important in the school effectiveness. It is reported that teachers who are happy with their school leadership work harder, become committed to duties and tend to grow willingness to innovate (Hallinger, 2003). Botswana School Effectiveness report of 1993 suggests that effective schools are those manned by visionary leaders with the ability to motivate others. The assumption being that for teachers to effectively execute their duties they should be motivated.

There are a number of theories formulated to describe leadership. The concept of effective leadership is derived from the business community, where there is a belief in the ability of leaders to change the character, performance and productivity of organizations (Barker, 2001). With this view leadership is conceptualised as an influence process. This is asserted by Jones and George (2009, p. 497) as they define leadership to mean "a process according to which a person exerts influence over others by inspiring them, motivating them and guiding their activities to help achieve goals and objectives of the organization." On the other hand, some authors believe that leadership is difficult to define and compared to beauty, which can only recognized by individuals when they see it (Bennis in Fidler, 1997); illustrated by the English proverb which says 'beauty is in the eyes of the beholder'. This suggests that a school manager cannot be a leader unless his followers perceive him/her as a leader.

The dilemma faced by school leaders is that in order to uphold their leadership they need to consider their capability to influence teachers in achieving the schools' goals. The capability is based on the effectiveness of the school leadership, leadership styles and staff motivation. Leadership exists at different levels - in teams, operational and strategic (Griffith, 2001; Fullan, 2002). The secret of having a highly motivated and performing staff is to have excellence in leadership at all levels. There are different styles that leaders use to influence their followers. These styles have impact on the success of organizations. It should also be noted that it is not only the staff which ought to be motivated; even leaders should be motivated as well. Before the mangers can think of motivating teachers they should be enthusiastic. This is asserted by Adair (2012, p. 91) that "the first and golden rule of motivation is that you will never inspire others unless you are inspired yourself."

\subsection{Effective School Leadership and Leadership Styles}

The reality of schools in Botswana nowadays, with constant strikes can put the school leader under considerable stress. In these scenarios school leaders should be effective in getting the best from staff members. In order to get the best from staff the leader must have regard for the need to encourage high morale, spirit of involvement and co-operation, and willingness to work. An effective leader is self-confident, enthusiastic, honest, knowledgeable, consistent, supportive, curious, exemplary and visionary (Daft, 2008). The leader will considerably adopt a particular leadership style, which emphasizes certain priorities and limits others. 
Leadership style can result out of experience, education, environment and many other factors. These leadership styles are said to have stable, consistent and predictable repercussions for the workplace climate for staff in order to perform well (Barker, 2011). The leadership styles have been classified as authoritarian/autocratic, democratic style, laissez-faire and paternalistic (Armstrong, 2011; Yem, 2012). The adoption of these forms of leadership in order to transfer information is situational.

\subsection{Effective School Leadership and Leadership Styles}

Leadership is to be distinguished from management in a school set up. Leadership is more concerned with 'doing the right things', whereas management is concerned with 'doing things right' (Harris et al 1996, 33). To be more specific Armstrong (2012,311) states that management is concerned with "achieving results by obtaining, deploying, using and controlling all the resources required namely people, money, facilities, plant and equipment, information and knowledge." Leadership focuses on the most important resource people. It is a process of developing and communicating a vision for the future, motivating people and gaining their engagement. This implies that being a leader means knowing where one is going and working to achieve a shared vision with colleagues. All leaders have to live with other people's view of their role. The people responsible to any leader have expectations about the way the leader ought to behave and will exert pressure to persuade him or her to conform to their views. Leaders have to reconcile these views with their own view of their role. Being a manager means getting things done which leads to the realization of the vision through other people.

\subsection{Motivation}

Since the days of Maslow researchers have studied organizations in search for theories of enhancing staff performance. WikiEducator (2013) described the characteristic motivation as having four models; affiliation motivation; power motivation; altruistic motivation and achievement motivation. The corner stone of the above models is that for teachers to be high performers depends on the power of their leaders to influence them. Some authors believe that power motivates managers to empower their subordinates (MacBeath, 1998). The success of any education system depends on the empowered and motivated teachers. All innovation put in place will only yield results if teachers have a motive to achieve. This motivation to achieve is known as achievement motivation (WikiEducator, 2013). A school will achieve its objectives and goals if teachers possess a high level of achievement motivation. Therefore, it is necessary to have an appropriate school leadership capability model in order to enhance achievement motivation among staff members for achievement of the school's goals.

Since there are few extrinsic motivating factors for teachers, school leaders should avail more intrinsic rewards to promote teacher motivation. Research has revealed that feeling of personal achievement, responsibility, autonomy, scope to use and develop skills and abilities, interesting and challenging work and opportunities are critical for teachers' motivation (Bishar, 1996). The school structure can also have an effect on teachers' motivation. If the culture of the school is one that believes in equal distribution of resources and rewards; and 
social relation are not stratified teachers seem to be highly motivated. Other extrinsic factors such as pay, praise, promotion, trust, encouragement and staff recognition can boost staff morale (Emerson \& Goddard, 1993).

\subsection{In Search for School Leadership Capability Model}

As alluded, the role of leadership has been recognized as the most critical for the success of any organization. It can be argued that one of the features which distinguish effective schools from ineffective schools is the quality of their leadership. Over the years several researches have been carried out in search of effective school leadership. Different types of school leadership such as moral, transformational, managerial, participative, instructional and contingent came to the fore. Some authors suggested three types of reaction to leadership approbation, neutrality and dislike (Fidler, 1997).

In 1994, thirty countries gathered at Melbourne to discuss among other themes the shifting ground of school leadership. This was initiated by what the countries viewed as policy shift towards devolution of responsibility to individual schools, emphasising on financial and contractual accountability, development of indicators of performance and stress on parents and public as consumers (MacBeath, 1998). These exerted pressure on the school leaders to satisfy their customers. This implied that a capacity model was required for better performance for the benefit both the leaders, teachers and clients. Capability as used in this article refers to the ability required to do something. Teachers, as practitioners are at the heart of education reform and addressing any change in individual teacher attitudes means understanding certain leadership models. Tomal (2007) came up with a theory designed for educators to help them understand their leadership style in motivating students called Leadership Capability Model. The model shows four types of leaders based 'upon the degree of the leader's competence and confidence.' Although the model could be used for motivating students, it is the feeling of the researcher that the same model can also be used for motivating teachers as was indicated by the study. The model could be used by school leaders to reflect on their practice in order understand and identify the appropriate approach need for effective teacher motivation.

As the search for school leadership capability model continued a number of leadership models were developed. Among the models include; 3-C Leadership model, Worthy Leadership model, Leadership Architect model, Leadership Capability model, Self-Leadership, Innovation and Creativity model and Communication, Shared Leadership, monitoring and Evaluation model. Since then, the search for building the senior management leadership capability has become a continuous effort.

\section{Methodology}

\subsection{Research Design}

The study used a positivist paradigm. A positivist paradigm is an idea in research where the truth can only be seen by observing, experimenting on and investigating a large sample, resulting in results which can be statistically analysed and generalised (Basit, 2010; Wellington, 2012). The fact that the sample of the study was not large enough some form of 
generalization was needed, hence the use of positivism paradigm. Amongst the positivists designs a survey design was adopted. A survey is commonly used to describe in some detail the respondents' ideas, experience and understanding of informants and the findings are claimed to be generalisable (Bulawa \& Mhlauli, 2012). Since the study sought respondents' views, experiences and opinions a survey was suitable. The study was conducted among ninety-six student teachers from the University of Botswana doing management courses in their third year level. This was a group of school managers who have enrolled at the university to upgrade their qualifications. The respondents were chosen on the basis that they have experience on the area of school leadership. The participants came from all the ten regions of the inspectorial areas. From the ninety-six participants, twenty-one were the School Heads; twenty-one were Deputy School Heads; fourty-eight were Heads of Department and six were Senior Teacher grade 1. Of the ninety-six participants, fifty-six were females and fourty were males. The respondents' age ranged between thirty-five years and fourty-five years and above. In terms of qualification ninety-three had a Diploma in Education and three possessed a Diploma in Management. As the sample was students of the researcher, convenience sampling was used. Convenience sampling is procedure where the researcher selects the participants because they are willing and available to be studied. Convenience sampling was favoured because the participants were readily available.

\subsection{Data Collection Techniques}

Data were collected through the use of a questionnaire. Questions were both open-ended and closed items. The questions were piloted using the fourth year student teachers who were school managers. Piloting was tried out for purposes of improving the questions' ability to do the job for which they are needed. Bell (1996, p. 84) argued that all data-gathering instruments should be piloted "to test how long it takes recipients to complete them, to check that all questions and instructions are clear and to enable you to remove any items which do not yield usable data." After the corrections were made the questions were ready to be used in the main research. The questionnaire was favoured following suggestions given in the literature that it tends to be more reliable, encourages greater honesty, it is economical in terms of money and time, and that respondents have time to give thoughtful answers (Cohen $\&$ Manion, 2007). The nature of the questionnaire was to give the respondents an opportunity to answer the questions openly and freely. The researcher administered the questionnaire.

\subsection{Data Analysis}

The study adopted a computer package form of data analysis normally used for quantitative research. The package is formerly known as the Statistical Package for Social science, but now appears as a modified version known as Statistical Product and Service Solution (SPSS) version 19. The Likert scale analysis followed Oppenheim's (1996) methods of working with the frequencies and percentages of the levels of agreement and disagreement of the respondents. The data analysis was presented in the form of frequency tables and percentages. As for open - ended questions themes were used and to some verbatim reporting was favoured to represent the views of the respondents. Different views from respondents were closely examined to make the data more meaningful and understood. 


\section{Findings and Discussions}

School leadership is widely recognized as one of the most critical aspects of school improvement and school effectiveness. It is an important contributing factor in the fulfillment of the school goals and objectives. Literature so far reviewed indicates that the school leadership plays and occupies a critical role in motivating the whole school community (Bennell \& Akyeampong, 2007). The research findings in this study have revealed that senior management uses different forms of models to motivate teachers in Botswana schools. The general feeling is that for effective teacher motivation the senior managers should be confident, competent and self- managing. The findings are discussed according to the Research Questions (RQ) and categorized into effectiveness of school leadership capability model, factors contributing towards teachers' motivation, school managers' understanding of leadership capability model and leadership capability model used.

\subsection{QR 1. School Leaders' Understanding of Leadership Capability Model}

This is an area where some of the respondents showed a limited understanding of a capability model. There was confusion between leadership styles and models. Fourty-four (46\%) of the participants in their descriptions gave examples of democratic, transformational, transactional, charisma and autocratic as types of models. The majority, fifty-six (54\%) showed that they understand the concept of leadership capability model by the use of words such as self-managing, confidence and competent when describing leadership capability model. A member of a senior management team had to say:

A leadership capability model is the ability possessed by leaders in order to do something with confidence, self-managing and being competent (Head of Department).

As the concept of leadership now changes from the traditional command and control model to a more cultivating and motivating model the school leaders should be have a sound understanding of leadership capability models. Ancona et al. (2006) developed a 4 Capabilities Leadership Framework for teaching leadership and other leadership. The purpose of the 4 Capabilities Leadership Framework is to help the leadership to realize their unique potential to initiate change. They describe this potential as a 'change signature - the leader's credo and characteristic way of creating change.' The leaders signature is based on his/her values, experience, tactics and personality in order to build trust, respect and authenticity.

Fullan $(2002$, p. 1) postulate that the school leader of the future should be "a leader in a culture of change." The school leader of tomorrow should be one with teacher transformation at heart for the success of his/her school. Leadership is about developing and communicating a vision for the future, motivating people and gaining their engagement (Armstrong, 2012). Therefore, the understanding of leadership capability model by school leaders is vital.

\subsection{RQ 2. Leadership Capability Model}

There are many leadership capability models which can be used to motivate teachers. These models are based on leadership practices used to enhance teachers professionalism for 
achieving the schools goals and objectives. All ninety-six (100\%) informants felt that senior management should be competent, confidence and self- managing to motivate teachers effectively as indicated in table 2 items 24-26. In the open-ended questionnaire regarding the type of leadership capability model majority eighty (83\%) state that they use various models which contains concepts of confidence, competence and self-managing. Such models are Self-leadership, Shared leadership model, Instructional models, Innovation and Creativity model and Communication model. A few sixteen (17\%) indicated that they use Monitoring and Evaluation model, Worthy Leadership model and Transitional model. From the study it is evident that the school managers do not have a particular capability model needed to motivate the teaching staff. They use a variety of models in the motivating process.

No definite leadership model is used, but one that comprises self-management and competence is top in the priority (Deputy School Head).

The informants believed that a school leader should possess certain qualities in order to an effective motivator. Responding to a question which requires to state qualities of an effective leader who is capable of motivating staff eighty $(83 \%)$ respondents mentioned self-confidence, enthusiasm, honesty and passionate, eight (8\%) mentioned knowledgeable, good communicator and good listener. Five (6\%) suggested intelligence and caring. While, three $(3 \%)$ suggested visionary as a quality for an effective leader. For instance, one of the respondents' asserts that:

In order to be an effective motivator one has to be confident and enthusiastic (School Head).

Respondents were required to list leadership styles that would be prescribed for schools in order for motivation to be sustained. Ten (11\%) mentioned democratic, six $(6 \%)$ mentioned charismatic and eighty (83\%) mentioned transformational leadership. One of the respondents says:

For the success for any school management a transformational leadership should prevail (Deputy School Head).

The study revealed that the school leaders use several leadership capability models to motivate the teaching force. Hazy (2006) expresses that leadership capability model posits that leadership is central to the process of change, variation, selection and retention. This process of change is the force that makes teachers motivated as a result of their needs being satisfied. These needs vary from one person to the other. As every teacher is unique, there is no single leadership capability model of motivation that would be effective for all. Therefore, it calls for school leaders to use different leadership capability models for motivating their teaching staff. Adair (2012) points out that how [school leaders] apply the leadership capability model will clearly depends on the situation.

\subsection{RQ 3: Effectiveness of School Leadership Capability Model}

Many senior managers in Botswana schools viewed the purpose of school leadership being effective in motivating teachers. Data were collected from closed - ended questions and open 
- ended questions which the participants responded to.

Table 1. Responses on effectiveness of school leadership capability model

\begin{tabular}{|c|c|c|c|c|c|c|c|c|c|c|}
\hline \multirow[b]{2}{*}{ Statement } & \multicolumn{10}{|c|}{ Participants Responses } \\
\hline & $\begin{array}{l}\mathrm{IE} \\
(\mathrm{Fr})\end{array}$ & $\%$ & $\begin{array}{l}\text { LE } \\
(\mathbf{F r})\end{array}$ & $\%$ & $\begin{array}{l}\text { E } \\
\text { (Fr) }\end{array}$ & $\%$ & $\begin{array}{l}\text { VE } \\
\text { (Fr) }\end{array}$ & $\%$ & $\mathbf{N}$ & $\%$ \\
\hline 7. Improves knowledge and skills & 5 & 5 & 16 & 17 & 67 & 70 & 8 & 8 & 96 & 100 \\
\hline 8. Promotes teachers cooperation & 5 & 5 & 16 & 17 & 56 & 58 & 19 & 20 & 96 & 100 \\
\hline 9. Enhances teachers performance & 8 & 8 & 13 & 14 & 51 & 53 & 24 & 25 & 96 & 100 \\
\hline 10. Instills self-control in teachers & 5 & 5 & 19 & 20 & 64 & 67 & 8 & 8 & 96 & 100 \\
\hline $\begin{array}{l}\text { 11. Helps teachers to acquire better } \\
\text { communication skills }\end{array}$ & 5 & 5 & 19 & 20 & 56 & 58 & 16 & 17 & 96 & 100 \\
\hline 12. Builds a sense of commitment & 5 & 5 & 24 & 25 & 56 & 58 & 11 & 11 & 96 & 100 \\
\hline $\begin{array}{l}\text { 13. Creates a well-disciplined teaching } \\
\text { force }\end{array}$ & 8 & 8 & 24 & 25 & 51 & 53 & 13 & 14 & 96 & 100 \\
\hline 14. Enhances teacher motivation & 8 & 8 & 13 & 14 & 48 & 50 & 27 & 28 & 96 & 100 \\
\hline $\begin{array}{l}\text { 15. Changes teachers' attitudes towards } \\
\text { teaching and learning }\end{array}$ & 5 & 5 & 33 & 34 & 45 & 47 & 13 & 14 & 96 & 100 \\
\hline
\end{tabular}

Key: $\%=$ per cent; $N=$ number of respondents; $F r=$ frequency; IE= ineffective; LE= less effective; $\mathrm{E}=$ effective; $\mathrm{VE}=$ very effective.

Table 1 shows informants feelings about the effectiveness of school leaders. This was based on its ability to improve teachers knowledge and skills, promote teachers cooperation, enhance teachers' performance, instill teachers self- control, acquisition of better communication skills, build a sense of compassion, create a disciplined staff, enhance teacher motivation and change teachers attitudes towards their own learning. It is indicated that the majority seventy-five (78\%) believe that school leadership improves teachers' knowledge and skills in problem - solving techniques, promotes teachers' cooperation, enhancing teachers' performance and enhances teacher motivation. Seventy-two (75\%) were adamant that school leadership instills self-control in teachers and helps teachers to acquire better communication skills. An average of sixty-three (66\%) strongly believed that school leadership builds a sense of compassion, creates a well-disciplined teaching force and changes teachers' attitudes towards their own learning. Regarding to the purpose of school leadership, eighty-eight (92\%) of the respondents mentioned leading, motivating and guiding, while eight (8\%) mentioned as resourcefulness. For instance, a member of senior management team says:

An effective leader should lead and motivate his staff (Head of Department).

Sharing the same sentiment a teacher affirms that:

School leaders are duty bound to guide their subordinates (Junior Teacher).

From the research findings above, it is certain that many informants perceive the school leadership as being effective in the development of teachers. The purpose of effective school 
leadership was echoed in WikiEducator (2013, p. 11) when stating that "it is evident that unless the school leadership is effective, a school as a whole will not be effective in its performance." From the literature so far reviewed it is clear that effective school leadership promotes teachers motivation and professional development (Bishar, 1996; Baker, 2011; Adair, 2012). Motivation boosts teachers' morale and encourages staff members to work harder.

\subsection{RQ 4: Factors Contributing Towards Teachers' Motivation}

There are many factors which contribute towards teachers' motivation. To investigate the informants' views data were collected from questions 16 - 23 and questions $29-30$. The respondents were also asked to show their degree of agreement with the statements given as shown in table 2 below. Table 2 illustrates factors that contribute towards teachers' motivation. This was based on the respondents' beliefs about teachers' motivation. All, ninety-six (100\%) believed that the school leadership ability to set direction for staff members, taking their obligation to motivate staff, staff involvement in decision making, setting realistic and challenging objectives, provision of rewards and staff recognition are detriment to staff motivation.

As leaders we should recognise our juniors' efforts by rewarding them (Deputy School Head).

A senior teacher supports other colleagues by saying:

Teachers should be recognized and involved in decision-making process to be highly motivated (Senior Teacher Grade II).

The dissatisfiers mentioned are lack of incentives and low salary. Another senior teacher says:

Low teachers' salary is a stumbling block towards the achievement of teachers' morale (Senior Teacher Grade I).

The study has revealed that factors such as staff recognition, incentives, staff involvement and better working conditions can improve staff motivation. Adair (2012) believes that fifty per cent of motivation comes from within a person and the other fifty per cent from his or her environment, especially from the leadership encountered there. Adair (2012, p. 108) continues to attest that for leaders to motivate staff they should "create a motivating environment, provide fair rewards and give recognition." Clarke (2012, p. 39) also emphasises that the things that matter and motivate people most are "less tangible things like the freedom to develop their own ideas and a sense of being valued." 
Table 2. Responses on factors which contribute towards teachers' motivation

\begin{tabular}{|c|c|c|c|c|c|c|c|c|c|c|}
\hline \multirow{2}{*}{ Statement } & \multicolumn{10}{|c|}{ Participants Responses } \\
\hline & S/D & $\%$ & $\mathbf{D}$ & $\%$ & $\mathbf{A}$ & $\%$ & $\mathbf{S} / \mathbf{A}$ & $\%$ & $\mathbf{N}$ & $\%$ \\
\hline 16. Purpose of school leadership & 0 & 0 & 0 & 0 & 13 & 14 & 83 & 86 & 96 & 100 \\
\hline $\begin{array}{l}\text { 17. Senior management is duty bound to } \\
\text { motivates its subordinates }\end{array}$ & 0 & 0 & 0 & 0 & 29 & 30 & 67 & 70 & 96 & 100 \\
\hline $\begin{array}{l}\text { 18. Senior managers have to be motivated to } \\
\text { motivate others }\end{array}$ & 0 & 0 & 0 & 0 & 13 & 14 & 83 & 86 & 96 & 100 \\
\hline $\begin{array}{l}\text { 19. Teachers must be asked what motivates } \\
\text { them }\end{array}$ & 5 & 5 & 8 & 8 & 32 & 33 & 51 & 53 & 96 & 100 \\
\hline $\begin{array}{l}\text { 20. Realistic and challenging objectives can } \\
\text { motivate teachers }\end{array}$ & 0 & 0 & 13 & 14 & 51 & 53 & 32 & 33 & 96 & 100 \\
\hline 21. Conducive working environment & 0 & 0 & 0 & 0 & 5 & 5 & 91 & 95 & 96 & 100 \\
\hline 22. Provision of rewards & 0 & 0 & 0 & 0 & 27 & 28 & 69 & 72 & 96 & 100 \\
\hline 23. Staff recognition & 0 & 0 & 0 & 0 & 16 & 17 & 80 & 83 & 96 & 100 \\
\hline 24. School managers competency & 0 & 0 & 0 & 0 & 16 & 17 & 80 & 83 & 96 & 100 \\
\hline $\begin{array}{l}\text { 25. Confidence is one the attributes of a } \\
\text { good motivator }\end{array}$ & 0 & 0 & 0 & 0 & 13 & 14 & 83 & 86 & 96 & 100 \\
\hline $\begin{array}{l}\text { 26. For effective motivation the school } \\
\text { manager should be self-managers }\end{array}$ & 0 & 0 & 0 & 0 & 29 & 31 & 67 & 69 & 96 & 100 \\
\hline
\end{tabular}

Key: $\%=$ per cent; $N=$ number of respondents; $F r=$ frequency; $S / D=$ strongly disagree; $\mathrm{D}=$ disagree; $\mathrm{A}=$ agree; $\mathrm{S} / \mathrm{A}=$ strongly agree.

From the research findings, it is clear that the majority believe that for a school leader to effectively motivate his/her teachers should possess certain qualities. The qualities should be building upon areas of competence, confidence and self-management. The qualities were affirmed by De Beer and Rossouw $(2012$, p. 38) when they state that "to be a good leader, a manager must have some of the following characteristics intelligence, self-confidence, integrity and honesty, knowledge and expertise and be a visionary." The study also revealed that transformational leadership practices can stimulate teachers' professional learning and motivation. Baker (2011) asserted that transformational leadership develops capability by motivating teachers to raise their level of personal commitment to school improvement. It can be argued that for the success of any school depends on the quality of leadership and the role played by the school leadership is critical to teachers' motivation.

\section{Limitation of the Study}

It is important to acknowledge the limitations of the study in view of the fact that readers ought to appreciate the context the study was carried out. The major limitations for selfsponsored researches are time and financial constraints. Due to time and financial constraints it was not possible to cover all school managers in the field. The study confined to $96(4.7 \%)$ of informants currently being in the management posts out of a population of approximately 2100 senior managers in Botswana junior secondary schools. Although the sample is relatively small, it is a representative of school leaders in the 206 junior secondary schools 
because the respondents were represented all ten inspectoral in the country. This brings the issue of generalisation which is vital in determining the validity and reliability of the research design.

The other limitation was failure to investigate the education officers. The education officers by virtue of their positions they are mandated to provide in-service training for teachers (Revised National Policy on Education, 1994). The Ministry of Education and Skills Development had introduced a number of interventions since the respondents left for further studies. Although the respondents are abreast with changes that take place in schools not all information reaches them. There might be issues and concerns that the respondents did not know at the time of the study. The education officers' views would act as a proof for or against allegations that there isn't any particular leadership capability model that school leaders use to motivate the teaching staff.

\section{Conclusions and Recommendations}

From the research findings it is clear that majority of the school managers use different types of leadership capability models to motivate their teaching force. Leadership capability models used by school leaders included Worthy Leadership model, Tomal's Leadership Capability model, Self-Leadership model, Innovation and Creativity model, Shared Leadership model and monitoring and Evaluation model. It is also shown that an effective school leadership can trigger both the intrinsic and extrinsic motivation. It could be argued that motivation at schools can take place in two ways: teachers can motivate themselves by seeking, finding and carrying out work that satisfies their needs; and teachers can be motivated by management by such methods as recognition, career progression and appreciation. There are many other factors which contribute to teachers' motivation which include; achievements, pay increase, responsibility, staff involvement in decision - making, work content and personal growth. An effective leader will be able to lead, inspire and motivate teachers. It could also be argued that an effective school leadership results into high quality teaching staff required for high quality education for the Batswana. The following recommendations are suggested for consideration:

- More in-service training on teacher motivation for school leaders should be provided by the Principal Education Officers at school-based workshops.

- School leaders should reward, recognize and appreciate teachers for the good work done.

- School leaders should involve staff on matters that affect them.

- A leadership capacity model which contains areas of self-management, confidence and competence should be adopted in order to strive for a highly motivated staff.

\section{Acknowledgements}

I would like to acknowledge the contributions made by Dr. Mavis B. Mhlaudi and Dr. Philip Bulawa after having read through the manuscript. 


\section{References}

Adair, J. (2012). Leadership and Motivation-The fifty - fifty rule and the eight key principles of motivating others. London: Kogan Page.

Ancona, D., Malone, T., Orlikowski, W., \& Senge, P. (2006). 4 Capabilities Leadership Framework. MIT Sloan Leadership Center, Available: http://mitleadership.mit.edu/r-dlm.php

Armstrong, M. (2012). Armstrong's handbook of Human Resource Management Practice. London \& Philadelphia: Kogan Page.

Baker, L. M. (2011). The Relationships between Leadership Practice and Teacher Motivation, Capacity, and Work Setting as Related to Change in Literacy Instruction. ProQuest LLC. 789 East Eisenhower Parkway, PO Box 1346, Ann Arbor, MI 48106.

Barker, B. (2001). Do leaders Matter? Educational Review, 53(1), 65-76. http://dx.doi.org/10.1080/00131910120033664

Bennell, P. (1995). A training policy for education professionals in Botswana. Gaborone: Government Printer.

Bennell, P., \& Akyeampong, K. (2007). Teacher Motivation in Sub-Saharan Africa and South Asia. Essex: Department for International Development Publications.

Bishay, A. (1996). Teacher Motivation and Job Satisfaction: A Study Employing the Experience Sampling Method. Journal of Undergraduate Sciences, 3, 147-154.

Bulawa, P., \& Mhlauli, M. B. (2012). Social Responsibilities of Schools in Botswana: The Role of Teachers in the Activities of the Community. International Journal of Social Sciences and Education, 2(1), 224-234.

Cohen, L., Manion, L., \& Morris, K. (2007). Research Methods in Education (6th ed.). London: Routledge.

Daft, R. L. (2008). Leadership Theory and Practice. Orlando: Harcourt Brace College Publishers.

De Beer, A., \& Rossouw, D. (2012). Focus on Management Principles - a generic approach. Capetown: Juta \& Company Ltd.

Emerson, C., \& Goddard, I. (1993). Managing Staff in Schools. Oxford: Heinemann.

Fidler, B. (1997). School Leadership: some key ideas. School Leadership \& Management, 17(1), 23-38. http://dx.doi.org/10.1080/13632439770140

Fullan, M. (2002). The Change Leader. Educational Leadership, 59(8), 16-21.

Griffith, J. (2001). Principal leadership of parent involvement. Journal of Educational Administration, 39(2), 162-186. http://dx.doi.org/10.1108/09578230110386287

Jones, G. R., \& George, J. M. (2009). Contemporary Management. Boston: McGraw - Hill. 


\section{Macrothink}

International Research in Education

ISSN 2327-5499

2014, Vol. 2, No. 1

Hazy, J. K. (2006). Measuring leadership effectiveness in complex social-technical systems. E:CO issue, 8(3), 58-77.

Leithwood, K., \& Jantzi, D. (2000). Principal and Teacher Leadership Effects: a replication. School Leadership \& Management, 20(4), 415-434. http://dx.doi.org/10.1080/13632430020003210

MacBeath, J. (1998). Effective School Leadership: Responding to Change. London: Paul Chapman Publishing Ltd.

Oppenheim, A. N. (1992). Questionnaire design, Interviewing and Attitude measurement. London: Printer Publishers.

Republic of Botswana. (1994). Revised National Policy on Education. Gaborone: Government Printer.

Republic of Botswana. (2003). Performance Based Reward System: Framework and Guidelines. Gaborone: Government Printer.

Tomal, D. R. (2007). Challenging Students to Learn. Lanham, MA: Rowman \& Littlefield.

Wellington, P. (2012). Managing Successful Teams. London: Kogan Page.

WikiEducator. (2013) Teacher Motivation. 1-14. Retrieved from http://wikieducator.org/Teacher_Motivation

Yemm, G. (2012). Essential Guides to Leading Your Team. New York: Pearson.

\section{Copyright Disclaimer}

Copyright reserved by the authors.

This article is an open-access article distributed under the terms and conditions of the Creative Commons Attribution license (http://creativecommons.org/licenses/by/3.0/). 